\title{
The impacts of internal and external factors on dynamics of traditional fishermen group in Manado reclamation area of Manado City, North Sulawesi Province
}

\section{Pengaruh faktor internal dan eksternal terhadap dinamika kelompok nelayan tradisional di kawasan reklamasi Pantai Kota Manado, Provinsi Sulawesi Utara}

\author{
Martha P. Wasak ${ }^{1 *}$, Jardie A. Andaki ${ }^{2}$, and Jeannette F. Pengemanan ${ }^{2}$ \\ ${ }^{1}$ Program Studi Ilmu Perairan, Program Pascasarjana Universitas Sam Ratulangi. Jln. Kampus Unsrat Kleak, \\ Manado 95115, Sulawesi Utara, Indonesia. \\ ${ }^{2}$ Fakultas Perikanan dan Ilmu Kelautan, Universitas Sam Ratulangi. Jl. Kampus Unsrat Bahu, Manado 95115, \\ Sulawesi Utara, Indonesia. \\ *E-mail: marthawasak@unsrat.ac.id
}

\begin{abstract}
A fishermen group is a forum for fishermen cooperation formed in one region to be able to become qualified fishermen. This requires that fishermen have the motion or power that can determine and influence the behavior of groups and their members in achieving their goals effectively. Fisherman groups should always be dynamic in running fishing business. This study aims to 1) analyze the factors that affect the dynamics of traditional fishing groups in the coastal reclamation area of Manado City, and 2) determine the dynamics model of traditional fishermen groups in the coastal reclamation area of Manado City. This research was conducted using survey method. $\mathrm{F}$ test statistics was used for mixed influence test and t-test statistic for partial test. Multiple linear regressions was conducted to describe the dynamics of traditional fishermen group in the coastal reclamation area of Manado City. The result of this research concluded that internal $\left(\mathrm{X}_{1}\right)$ and external $\left(\mathrm{X}_{2}\right)$ factors together or partially has an effect on dynamics of traditional fisherman group of coastal reclamation area of Manado City. Partially, internal sub factor (education level and experience of fishing effort) and external sub factor (the availability of capital aid and information availability) have real effect on dynamics of traditional fisherman group of coastal reclamation area of Manado City. The dynamic equation model of traditional coastal reclamation area of Manado City is $\mathrm{Y}=0,770774+0,344691 \mathrm{X}_{1}+0,388735 \mathrm{X}_{2}$.
\end{abstract}

Keywords: land reclamation area; fishermen; coastal management; Manado; North Sulawesi.

Abstrak: Kelompok nelayan merupakan wadah kerjasama dari nelayan dalam satu wilayah untuk dapat mencapai nelayan yang berkualitas. Hal ini mengharuskan nelayan memiliki gerak atau kekuatan yang dapat menentukan dan mempengaruhi perilaku kelompok dan anggota-anggotanya dalam mencapai tujuan secara efektif. Kelompok nelayan harus selalu dinamis dalam menjalankan usaha penangkapan ikan. Penelitian ini bertujuan untuk 1) menganalisis faktor-faktor yang mempengaruhi dinamika kelompok nelayan tradisional di kawasan reklamasi pantai Kota Manado, dan 2) menentukan model dinamika kelompok nelayan tradisional di kawasan reklamasi pantai Kota Manado. Penelitian ini mengunakan metode survey. Statistika Uji-F digunakan untuk uji pengaruh secara bersama-sama dan Statistika Uji-t untuk uji parsial. Regresi linear berganda dilakukan untuk menggambarkan persamaan dinamika kelompok nelayan tradisional di kawasan reklamasi pantai Kota Manado. Dari hasil penelitian dapat disimpulkan, bahwa faktor internal $\left(\mathrm{X}_{1}\right)$ dan eksternal $\left(\mathrm{X}_{2}\right)$ secara bersama-sama maupun parsial berpengaruh nyata terhadap dinamika kelompok nelayan tradisional. Secara parsial sub-faktor internal (tingkat pendidikan dan pengalaman usaha penangkapan ikan) dan sub-faktor eksternal (ketersediaan bantuan modal dan ketersediaan informasi) berpengaruh nyata terhadap dinamika kelompok nelayan tradisional. Model persamaan dinamika kelompok nelayan tradisional kawasan reklamasi pantai Kota Manado, yaitu: $\mathrm{Y}=$ $0,770774+0,344691 X_{1}+0,388735 X_{2}$.

Kata-kata kunci: reklamasi pantai; nelayan; pengelolaan pesisir; Manado; Sulawesi Utara.

\section{PENDAHULUAN}

Kelompok nelayan tradisional merupakan bentuk kelompok sosial yang telah ada di Kota Manado. Ketersediaan sumber daya ikan di perairan Kota
Manado mendorong masyarakat untuk menjalankan usaha penangkapan ikan. Awal mula penangkapan ikan dilakukan untuk konsumsi (subsisten), namun seiring dengan pertumbuhan pendudukan kota, maka kebutuhan akan ikan menjadi peluang usaha 
Wasak et al.: The impacts of internal and external factors on dynamics of traditional fisherman group ...

bukan saja subsisten, namun dapat diperdagangkan melalui saluran pemasaran.

Nelayan tradisional hingga saat ini, masih menunjukkan eksistensinya dengan munculnya kelompok-kelompok nelayan tradisional. Kegiatan reklamasi pantai di Kota Manado sempat memporak-porandakan kehidupan nelayan tradisional, namun kelompok sosial nelayan tradisional telah menjadi mediator potensial untuk mendapatkan hak pengelolaan pantai berupa ruang tambatan perahu dan mempertahankan eksistensinya pasca reklamasi (Andaki, 2012). Keberadaan kelompok nelayan tradisional ini tidak terlepas dari dinamika kelompok dalam usaha penangkapan ikan.

Sehubungan dengan pencapaian tujuantujuan kelompok secara efektif, maka menjadi suatu keharusan, bahwa kelompok nelayan harus memiliki gerak atau kekuatan yang dapat menentukan dan mempengaruhi perilaku kelompok dan anggota-anggotanya. Kelompok nelayan harus selalu dinamis sehingga dapat berfungsi efektif bagi kepentingan para anggotanya untuk mencapai tujuan dalam menjalankan usaha penangkapan ikan. Oleh karena itu, perlu dilakukan kegiatan penelitian untuk mengkaji pengaruh faktor internal dan eksternal terhadap dinamika kelompok nelayan dalam usaha penangkapan ikan.

Penelitian ini bertujuan untuk: 1) menganalisis faktor-faktor yang mempengaruhi dinamika kelompok nelayan tradisional di kawasan reklamasi pantai Kota Manado, dan 2) menentukan model dinamika kelompok nelayan tradisional di kawasan reklamasi pantai Kota Manado.

\section{MATERIAL DAN METODA}

Metode yang digunakan dalam penelitian ini adalah metode survei, yaitu penelitian yang mengambil sampel dari satu populasi dan menggunakan kuisioner sebagai alat pengumpulan data yang pokok. Penelitian survei menitikberatkan pada penelitian relasional, yaitu mempelajari hubungan variabel-variabel sehingga secara langsung atau tidak hipotesis penelitian dipertanyakan (Singarimbun, 2006).

Populasi dalam penelitian ini adalah nelayan, yang menjadi anggota kelompok nelayan di kawasan reklamasi pantai Kota Manado. Nama kelompok nelayan yang dijadikan responden, yaitu: 1) Ikhtus I, 2) Ikhtus II, 3) Lumba-lumba I, 4) Lumba-lumba II, 5) Bintang Laut, 6) Malos I, 7) Malos II, dan 8) Malos III.

Analisis Statistika deskriptif dilakukan untuk mendeskripsikan atau memberi gambaran terhadap objek yang diteliti (Sugiyono, 2004). Data pada penelitian ini meliputi variabel faktor internal $\left(\mathrm{X}_{1}\right)$, faktor eksternal $\left(\mathrm{X}_{2}\right)$, dan dinamika kelompok $(\mathrm{Y})$. Guna mengetahui model/persamaan dinamika kelompok nelayan tradisional kawasan reklamasi pantai Kota Manado, maka digunakan analisis regresi linear berganda dengan formula: $\mathrm{Y}=\mathrm{a}+$ $\beta_{1} X_{1}+\beta_{2} X_{2}+\varepsilon$. Statistika Uji-F digunakan untuk menguji pengaruh secara bersama-sama dan Statistika Uji-t untuk menguji secara parsial (Walpole, 1995)

\section{HASIL DAN PEMBAHASAN}

\section{Analisis Regresi Gabungan Faktor Internal dan Eksternal terhadap Dinamika Kelompok}

Output analisis ini dapat membentuk persamaan regresi, sebagai berikut:

$$
\mathrm{Y}=0,770774+0,344691 \mathrm{X}_{1}+0,388735 \mathrm{X}_{2}
$$

Dapat dilihat, bahwa nilai konstanta (a) adalah sebesar 0,770774. Hal ini berarti, jika faktor internal dan faktor eksternal bernilai 0, maka dinamika kelompok bernilai 0,770774 (kategori rendah). Nilai koefisien regresi variabel internal $\left(\beta_{1}\right)$ bernilai positif, yaitu 0,344691. Hal ini dapat diartikan, bahwa setiap peningkatan faktor internal sebesar 1 kategori, maka nilai dinamika kelompok akan menurun sebesar 0,344691 kategori, ceteris paribus.

Nilai koefisien regresi varibel eskternal $\left(\beta_{2}\right)$ bernilai positif, yaitu 0,388735 . Hal ini berarti setiap peningkatan faktor eksternal sebesar 1 kategori, maka dinamika kelompok juga akan meningkat sebesar 0,388735 kategori, ceteris paribus.

\section{Analisis Hubungan dan Pengaruh Faktor Internal terhadap Dinamika Kelompok}

Hasil output diketahui nilai Significance F sebesar $0,000207127<0,05$, kesimpulannya adalah tersapat pengaruh "sangat nyata" secara bersamasama antara variabel umur $\left(\mathrm{X}_{1.1}\right)$; tingkat pendidikan $\left(\mathrm{X}_{1.2}\right)$; dan pengalaman usaha penangkapan ikan $\left(\mathrm{X}_{1.3}\right)$ terhadap dinamika kelompok (Y).

Output program tersebut diketahui nilai signifikasi untuk variabel umur $\left(\mathrm{X}_{1.1}\right)$ besarnya signifikasi ialah $0,813654872(p>0,05)$. Jadi, kesimpulannya, tidak ada pengaruh signifikan variabel umur $\left(\mathrm{X}_{1.1}\right)$ terhadap dinamika kelompok $(\mathrm{Y})$, ceteris paribus atau $\mathrm{X}_{1.2}$ dan $\mathrm{X}_{1.3}$ konstan. Hasil ini mengindikasikan, bahwa umur tidak berpengaruh nyata terhadap dinamikan kelompok nelayan tradisional kawasan reklamasi pantai Kota Manado. 
Variabel tingkat pendidikan $\left(\mathrm{X}_{1.2}\right)$ besarnya signifikasi ialah 3,43149E-05 $(\mathrm{p}<0,05)$. Jadi, kesimpulannya, ada pengaruh signifikan antara tingkat pendidikan $\left(\mathrm{X}_{1.2}\right)$ terhadap dinamika kelompok (Y), ceteris paribus. Tingkat pendidikan merupakan faktor penting terhadap dinamika kelompok. Menurut Chaskin et al. (2001), pengertian pendidikan dapat dibagi menjadi tiga, yakni secara sempit, secara luas, dan secara alternatif. Pendidikan secara luas mengartikan, bahwa pendidikan sebagai hidup.

Pendidikan merupakan segala pengalaman belajar yang berlangsung dalam lingkungan dan sepanjang hidup (long life education). Pendidikan merupakan segala situasi hidup yang mempengaruhi terhadap pertumbuhan individu. Secara simplistik, pendidikan didefinisikan sebagai sekolah, yakni pengajaran yang dilaksanakan atau diselenggarakan di sekolah sebagai lembaga pendidikan formal. Pendidikan merupakan segala pengaruh yang diupayakan terhadap anak dan remaja yang diserahkan kepadanya agar mempunyai kemampuan yang sempurna dan kesadaran penuh terhadap hubungan-hubungan dan tugas sosial mereka.

Variabel pengalaman usaha penangkapan ikan $\left(\mathrm{X}_{1.3}\right)$ besarnya signifikasi ialah 0,033856204 $(p<0,05)$. Jadi, kesimpulannya, ada pengaruh nyata secara parsial antara pengalaman usaha penangkapan ikan $\left(\mathrm{X}_{1.3}\right)$ terhadap dinamika kelompok (Y), ceteris paribus. Pengalaman usaha penangkapan ikan merupakan komponen penting dalam dinamika kelompok. Menurut Wiseman (1995) dalam Andaki (2012), pengalaman terkait juga dengan proses adaptasi. Adaptasi merupakan tujuan hidup yang mendasar dan seseorang berbuat serta menyesuaikan diri sebagai suatu keberanian menghadapi tantangan; hal mana adaptasi terus terjadi pada diri individu sejauh mereka menggunakan lingkungan sosiokultur dari pesan yang mereka kirim dan mereka terima.

Menurut Altman dalam Gifford (1987) yang disitasi Andaki (2012), adaptasi diartikan sebagai kapasitas individu untuk mengatasi lingkungan, yang merupakan proses tingkah laku umum yang didasarkan atas faktor-faktor psikologi untuk melakukan antisipasi kemampuan melihat tuntutan di masa yang akan datang. Berdasarkan pernyataan ini jelas, bahwa pengalaman sebagai nelayan akan memproses pribadi seseorang mengusai dan mengembangkan teknik usaha penangkapan ikan yang menguntung-kan bagi kehidupan nelayan.

\section{Analisis Hubungan dan Pengaruh Faktor Eksternal terhadap Dinamika Kelompok}

Hasil output diketahui nilai Significance $F$ sebesar 8,49397E-06 <0,05; kesimpulannya, ada pengaruh sangat nyata secara bersama-sama variabel intensitas penyuluhan $\left(\mathrm{X}_{2.1}\right)$; ketersediaan bantuan modal $\left(\mathrm{X}_{2.2}\right)$; peran pendamping $\left(\mathrm{X}_{2.3}\right)$; dan ketersediaan informasi $\left(\mathrm{X}_{2.4}\right)$ terhadap dinamika kelompok (Y).

Output program tersebut diketahuinya nilai signifikasi untuk variabel intensitas penyuluhan $\left(\mathrm{X}_{2.1}\right)$, yang besar signifikasinya ialah 0,122345447 $(p>0,05)$. Jadi, kesimpulannya, tidak ada pengaruh signifikan variabel intensitas penyuluhan $\left(\mathrm{X}_{2.1}\right)$ terhadap dinamika kelompok $(\mathrm{Y})$, ceteris paribus atau $\mathrm{X}_{2.2} \mathrm{X}_{2.3}$ dan $\mathrm{X}_{2.4}$ konstan. Hasil ini mengindikasikan, bahwa intensitas penyuluhan tidak berpengaruh nyata terhadap dinamika kelompok nelayan tradisional kawasan reklamasi pantai Kota Manado.

Variabel ketersediaan bantuan modal $\left(\mathrm{X}_{2.2}\right)$; besarnya signifikasinya ialah 0,022699234 $(p<0,05)$. Jadi, kesimpulannya, ada pengaruh signifikan antara ketersediaan bantuan modal $\left(\mathrm{X}_{2.2}\right)$ terhadap dinamika kelompok (Y), ceteris paribus. Ketersediaan bantuan modal merupakan faktor penting terhadap dinamika kelompok.

Variabel peran pendamping $\left(\mathrm{X}_{2.3}\right)$; besarnya signifikasi ialah 0,269379896 ( $p>0,05)$. Jadi, kesimpulannya, tidak ada pengaruh nyata secara parsial antara peran pendamping $\left(\mathrm{X}_{2.3}\right)$ terhadap dinamika kelompok $(\mathrm{Y})$, ceteris paribus.

Variabel ketersediaan informasi $\left(\mathrm{X}_{2.4}\right)$; besarnya signifikasi ialah 0,000427316 $(p<0,05)$. Jadi, kesimpulannya, ada pengaruh nyata secara parsial antara ketersediaan informasi $\left(\mathrm{X}_{2.4}\right)$ terhadap dinamika kelompok (Y), ceteris paribus.

\section{KESIMPULAN}

1. Faktor internal $\left(\mathrm{X}_{1}\right)$ dan eksternal $\left(\mathrm{X}_{2}\right)$, baik secara bersama-sama maupun parsial, berpengaruh nyata terhadap dinamika kelompok nelayan tradisional kawasan reklamasi pantai Kota Manado. Secara parsial sub-faktor internal (tingkat pendidikan dan pengalaman usaha penangkapan ikan) dan sub-faktor eksternal (ketersediaan bantuan modal dan ketersediaan informasi) berpengaruh nyata terhadap dinamika kelompok nelayan tradisional kawasan reklamasi pantai Kota Manado. 
Wasak et al.: The impacts of internal and external factors on dynamics of traditional fisherman group ...

2. Model persamaan dinamika kelompok nelayan tradisional kawasan reklamasi pantai Kota Manado, yaitu: $\mathrm{Y}=0,770774+0,344691 \mathrm{X}_{1}+$ $0,388735 \mathrm{X}_{2}$.

\section{REFERENSI}

ANDAKI, J.A. (2012) Masyarakat Pantai Kota Manado Pasca Reklamasi. Disertasi. Bandung: Program Pascasarjana Universitas Padjadjaran Bandung.

CHASKIN, R.J., BROWN, P., VENKATESH, S. and VIDAL, A. (2001) Building Community Capacity. New York: Walter de gayte, Inc.

DAHURI, R. (2000) Pendayagunaan Sumber daya Kelautan Untuk Kesejahteraan Rakyat. Jakarta: Penerbit Lembaga Informasi dan Studi Pembangunan Indonesia.
KUSNADI (2002) Konflik Sosial Nelayan Kemiskinan dan Perebutan Sumber Daya Perikanan. Yogyakarta: PT. LKIS Pelangi Aksara.

KUSNADI (2009) Kebudayaan Nelayan dan Dinamika Ekonomi Pesisir. Yogyakarta: Anruzz Media.

SINGARIMBUN, M. (2006) Cara Pemenuhan Kebutuhan Pokok Rakyat Miskin. Jakarta: Penerbit CV Rajawali.

SUGIYONO. (2004) Statistika Untuk Penelitian. Bandung: CV. Alfabeta.

WALPOLE, R.E. (1995) Pengantar Statistika (Terjemahan). Jakarta: PT Gramedia Pustaka Utama.

Received: 14 August 2018 Accepted: 25 September 2018 